\title{
Transformation in Micrococcus lysodeikticus
}

\author{
By W. E. KLOOS \\ Department of Genetics \\ AND L. M. SCHULTES \\ Department of Microbiology, North Carolina State University, \\ Raleigh, North Carolina, U.S.A. 27607
}

(Accepted for publication I6 October 1968)

\begin{abstract}
SUMMARY
Phage N6 lysates of Micrococcus lysodeikticus and Sarcina lutea were very viscous and were found to mediate genetic transfer of an adenine marker $\left(\mathrm{ade}^{+}\right)$to adenine-dependent strains of $M$. lysodeikticus. The transfer activity of these lysates was found to reside in a high molecular weight DNA fraction rather than in the phage particles themselves. DNA that was isolated and purified from phage lysates and lysozyme-treated cells was shown to possess transforming activity. Recipient competence was maximal during late logarithmic growth (I4-I $8 \mathrm{hr}$ ). The cell density of the transfer suspension was optimum at about $1 \mathrm{O}^{7}$ colony forming units $/ \mathrm{ml}$. Transformants were recovered after I hr exposure to DNA and continued to increase in number up to $6 \mathrm{hr}$. Transformants appeared in higher frequencies on Difco agars that were less purified. Under optimal conditions, transformation frequencies up to several percent per colony forming unit were obtained. All strains of M. lysodeikticus tested (ATCC 4698, ATCC I580I, CCM I335, PU, UM, WRU, ISU) could serve as donors of the ade ${ }^{+}$marker. All strains, except ATCC 4698, were competent recipients of the adenine marker.
\end{abstract}

\section{INTRODUCTION}

The 'species' Micrococcus lysodeikticus originated from a single culture isolated by Fleming (1922). He discovered that the organism was very susceptible to the lytic action of lysozyme and, since this early study, it has been widely used as a source of cell-wall substrate for lysozyme assay. Numerous studies have been conducted on its cell wall and membrane structure and various enzyme systems.

Cultures maintained by different laboratories have shown some variation over a period of time (Feiner, Meyer \& Steinberg, I946; Grula, 1962), presumably as a result of subculture and other selective processes. More specific variation has been obtained by the isolation of certain mutants to study various features of the organism (Feiner, 1967; Fleming \& Allison, 1927; Naylor \& Burgi, 1956; Okubo, Nakayama, Sekiguchi \& Takagi, I967; Stechschulte, I96I). Only recently, however, has this organism been subjected to genetic analysis. The first evidence of genetic exchange was reported in certain crosses using phage N6 lysates capable of transmitting an adenine marker (Kloos, I968).

This report will provide evidence of the mechanism of genetic transfer mediated by phage N6 lysates. The nature of the transfer agent (e.g. free DNA or phage particles) 
was first elucidated by treating phage lysates with deoxyribonuclease (DNase), heat, and phage-specific antiserum. Since these studies indicated that free DNA and not phage particles themselves were involved in transfer, we continued to pursue the isolation of transforming DNA. Preliminary studies are included which determine some of the optimum conditions for transformation and survey donor and recipient competence of a number of different strains.

Table I. Strains and mutants of Micrococcus lysodeikticus

\begin{tabular}{|c|c|}
\hline Strains & $\begin{array}{c}\text { Genetic } \\
\text { characters }\end{array}$ \\
\hline ATCC 4698 & ade pig-y \\
\hline ATCC 15801 & ade pig-p \\
\hline ATCC 15801 & $a d e^{+}-4$ pig-p \\
\hline CCM I 335 & $a d e^{+} p i g-y$ \\
\hline PU & ade pig-y \\
\hline PU & $a d e^{+-8}$ pig-y \\
\hline UM & ade pig-y \\
\hline UM & ade $+-I$ pig-y \\
\hline WRU & ade pig-y \\
\hline WRU & ade +- pig-y \\
\hline ISU & ade pig-y \\
\hline ISU & ade pig-o \\
\hline ISU & $a d e^{+}-I$ pig-y \\
\hline
\end{tabular}

Source

J. B. Evans, North Carolina State Univ., Raleigh, N.C., U.S.A.

American Type Culture Collection, Rockville, Maryland, U.S.A.

M. Kocur, Czechoslovak Collection of Microorganisms, J. E. Purkyne Univ., Brno, CSSR

E. A. Grula, Oklahoma State Univ., Stillwater, Okla., U.S.A.

E. A. Grula

E. A. Grula

E. A. Grula

\section{METHODS}

Bacterial strains. Strains and mutants of Micrococcus lysodeikticus used in this study are listed in Table I. The strain of Sarcina lutea used in crosses with $M$. lysodeikticus was ATCC 272 obtained from M. Kocur.

The phenotypic markers used to test genetic exchange included: (I) the ability of a strain to grow in the absence of adenine and (2) colonial pigment. These characters differed among several strains and could be easily scored. Most of the laboratory strains required adenine for growth. With the adenine-dependent strains used in this study, adenosine, inosine, or hypoxanthine could replace adenine and even produce a more rapid growth response (Grula, 1962). Strain CCM I335 was adenine-independent and was used as a donor. Spontaneous adenine-independent mutants were readily obtained from all strains, except ATCC 4698, and were also tested as donors. The two spontaneous pigment mutants used in this study were isolated from wild-type, yellow strains. The marker system used to test genetic exchange between Sarcina lutea and Micrococcus lysodeikticus utilized the natural adenine-independent $S$. lutea as donor with adenine-dependent strains of $M$. lysodeikticus.

The designation of markers was made according to the scheme of Demerec, Adelberg, Clark \& Hartman (I966) whenever possible. The adenine-dependent strains were designated ade. Adenine-independent mutants were designated ade $e^{+}$followed by an arabic numeral to indicate the order of isolation; e.g. ade ${ }^{+}$-I. Colonial pigment was denoted by the term pig with the addition of a hyphenated symbol to indicate the particular colour. The following terms were used: pig- $y$, yellow; pig- $p$, pale pink or beige; pig-o, orange or apricot. 
Media and conditions of growth. The complex broth ( $\mathrm{P}$ broth) and agar (P agar) used throughout this study were described by Naylor \& Burgi (1956). The defined agar used was a modification of the defined medium of Wolin \& Naylor (1957) supplemented with certain amino acids required for rapid growth on agar (Rose \& Kloos, unpublished data). The composition of the synthetic agar is as follows: $\mathrm{K}_{2} \mathrm{HPO}_{4}, 2 \mathrm{~g}$.; $\mathrm{NH}_{4} \mathrm{Cl}$, I g.; $\mathrm{MgSO}_{4} \cdot 7 \mathrm{H}_{2} \mathrm{O}$, 0.I g.; $\mathrm{FeSO}_{4} \cdot 7 \mathrm{H}_{2} \mathrm{O}, 4 \mathrm{mg}$.; $\mathrm{MnCl}_{2} \cdot 4 \mathrm{H}_{2} \mathrm{O}, 2 \mathrm{mg}$.; glucose, $7 \mathrm{~g}$.; biotin, Io $\mu$ g.; monosodium glutamate, $10 \mathrm{~g}$.; L-arginine, $656 \mathrm{mg}$; L-phenylalanine, $400 \mathrm{mg}$; L-tyrosine, $500 \mathrm{mg}$; L-proline, $900 \mathrm{mg}$.; L-isoleucine, $500 \mathrm{mg}$; L-cysteine, $480 \mathrm{mg}$.; L-methionine, $270 \mathrm{mg}$.; Special Agar-Noble (Difco), $15 \mathrm{gm}$.; de-ionized water, $1000 \mathrm{ml}$. Glucose was added aseptically after sterilization of the medium. The $\mathrm{pH}$ of the medium was adjusted to $7 \cdot 2$ before autoclaving.

Bacteria were maintained at $4^{\circ}$ on $\mathrm{P}$ agar slants in cotton-plugged tubes. The inocula for all experiments were obtained from subcultures of stocks which were prepared on $\mathrm{P}$ agar slants incubated for $\mathrm{I} 8 \mathrm{hr}$ and then stored. Cultures were shaken with a Burrell Wrist-Action Shaker (Burrell Corporation, Pittsburgh, Pennsylvania) at a setting of 4 with arms mounted over water baths at $32^{\circ}$.

Bacteriophage. The micrococcal phage N6, propagated on Micrococcus lysodeikticus ATCC I580I, was used to prepare lysates of $M$. lysodeikticus strains. This phage was described by Naylor \& Burgi (1956) and was obtained from M. Kocur. A host-range mutant of phage N6 was isolated and used to prepare lysates of Sarcina lutea. Phages were stored in $\mathrm{P}$ broth in screw-capped tubes at $4^{\circ}$.

Preparation of phage lysates. Phages were propagated on the appropriate donor strain by a modification of the agar-layer technique of Swanstrom \& Adams (I95I). Propagation was for 18 to $24 \mathrm{hr}$. The soft $\mathrm{P}$ agar layer was suspended in $8 \mathrm{ml}$. of $P$ broth and homogenized by repeated passage through a $10 \mathrm{ml}$. pipette. After centrifugation, lysates were bacteriologically sterilized by filtration through an 02 Selas Filter (Selas Flotronics, Spring House, Pennsylvania, U.S.A.) and then stored at $4^{\circ}$. They usually had titres from $10^{10}$ to $10^{11}$ plaque forming units (p.f.u.)/ml.

Preparation of lysozyme lysates. Lysozyme lysates were obtained by treating $\mathrm{I} 8 \mathrm{hr}$ broth cultures $\left(2-4 \times 10^{9}\right.$ colony-forming units $/ \mathrm{ml}$. c.f.u. $/ \mathrm{ml}$.) of the appropriate donor strain with lysozyme (Difco) $(20 \mu \mathrm{g}$. $/ \mathrm{ml}$.) for I hr. The suspension was then centrifuged to remove cell debris and bacteriologically sterilized by filtration through an 20 Selas Filter. The filtrate was heated at $75^{\circ}$ for $30 \mathrm{~min}$. to remove lysozyme activity.

Procedure for crosses with lysates. An $18 \mathrm{hr} \mathrm{P}$ agar slant culture $\left(5-10 \times 10^{9}\right.$ colony forming units) of the recipient strain was suspended in I ml. P broth. A O.I ml. sample of this suspension was then added to $\mathrm{I} \mathrm{ml}$. of phage or lysozyme lysate and the mixture (transfer suspension) shaken for $30 \mathrm{~min}$. The shaken suspension was washed once by centrifugation and resuspended in I $\mathrm{ml}$. saline. Samples of $0.1 \mathrm{ml}$. were spread on the appropriate medium and scored after incubation for 6 days.

DNase treatment. DNase (I $\times$ crystallized, Worthington Biochemical Corporation, Freehold, New Jersey) was added to phage lysates at concentrations of $10^{-4} \mu \mathrm{g} . / \mathrm{ml}$. to $100 \mu \mathrm{g} . / \mathrm{ml}$. Magnesium sulphate was added to a final concentration of $0.005 \mathrm{M}$. The mixture was incubated at $37^{\circ}$ for $30 \mathrm{~min}$. and then used to prepare the transfer suspension.

Heat treatment. Phage lysates were heated at different temperatures from $32^{\circ}$ to $100^{\circ}$ for $\mathrm{I} \mathrm{hr}$ and then cooled rapidly in an ice-bath for $15 \mathrm{~min}$. The cooled lysate was then warmed at $32^{\circ}$ and used to prepare the transfer suspension. 
Preparation of serum. The preparation of phage N6 antigen was according to the method of Burgi (1955). Phage specific antiserum was prepared by injecting rabbits intravenously with I ml. of antigen on days I, 3, 7, I5, and 23. Antiserum was collected 7 days after the last injection. Normal serum and antiserum were diluted $\mathrm{I} / \mathrm{ro}$ in 0.0 I M-phosphate buffer and heated at $75^{\circ}$ for $45 \mathrm{~min}$. to remove complement and nuclease activity. Sera were incubated with cells of the recipient strain for $4 \mathrm{hr}$ to remove most of the cell antibodies. Further purification by ammonium sulphate fractionation and dialysis was required to remove material in both normal serum and antiserum that reduced the yield of recombinants in tests.

Serum treatment. Phage lysates were treated with normal serum or antiserum by adding $\mathrm{I} \mathrm{ml}$. of serum to $\mathrm{I} \mathrm{ml}$. of lysate and incubating the mixture for $2 \mathrm{hr}$ at $32^{\circ}$. Transfer suspensions were prepared by using the total volume $(2 \mathrm{ml}$.) of treated lysates.

Procedure for DNA isolation and purification. The procedure used to obtain purified DNA was that of Marmur (I96I) with the modification of Saito \& Miura (1963) using TI ribonuclease (RNase) (Sankyo Company, Ltd., Tokyo, Japan) as well as bovine pancreatic RNase (Calbiochem, Los Angeles, California). DNA was isolated from Micrococcus lysodeikticus cells by treatment with lysozyme (Pentex Incorp., Kankakee, Illinois) and from phage N6 lysates without prior lysozyme treatment. All preparations were de-proteinized 4 times both before and after RNase treatment. After the final ethanol precipitation, DNA was dispersed into a I/Io dilution of standard saline-citrate buffer (SSC: $0.15 \mathrm{M}-\mathrm{NaCl}+0.015 \mathrm{M}$-sodium citrate, $\mathrm{pH} 7^{\circ}$ ) which was later adjusted to SSC. Chloroform was added to purified DNA preparations to maintain bacterial sterility.

DNA concentration was determined by the diphenylamine reaction of Dische (1955). RNA was estimated by the orcinol reaction (Brown, I946; Mejbaum, 1939) and protein by the method of Lowry, Rosebrough, Farr \& Randall (I95I). DNA base ratios were determined by the thermal denaturation method of Marmur \& Doty (I962).

Procedure for crosses using purified DNA. An I $8 \mathrm{hr} \mathrm{P}$ agar slant culture of the recipient strain was suspended in $\mathrm{I} \mathrm{ml}$. $\mathrm{P}$ broth. A $\mathrm{IO}^{-2}$ dilution of this suspension in broth was prepared and a $0.1 \mathrm{ml}$. sample added to $\mathrm{I} \mathrm{ml}$. of purified DNA preparation. The transfer suspension was shaken for $2 \mathrm{hr}$, washed once by centrifugation, and resuspended in I $\mathrm{ml}$. saline. Samples of $0.1 \mathrm{ml}$. from the concentrated suspension and a $1 \mathrm{O}^{-1}$ dilution in saline were spread on duplicate synthetic agar plates and scored after incubation for 6 days.

\section{RESULTS}

Demonstration of genetic transfer. The ability of phage N6 lysates to transfer genetic information from donor to recipient cells of Micrococcus lysodeikticus was demonstrated in two separate crosses using strains that differed in genetic characters (Table 2). Several hundred recombinant clones from each cross were isolated and tested for genetic stability. All maintained the recombinant phenotype on repeated agar transfer. Donor contamination was eliminated as a source of clones by the following observations: (a) samples from phage lysates that were filtered did not contain donor cells; (b) donor cells which were added to phage lysates appeared on synthetic agar at least $24 \mathrm{hr}$ earlier than $\mathrm{Ade}^{+}$recombinants and possessed characteristics (colonial pigment, ability to support phage N6 plaque formation, growth) of the donor strain; (c) recombinants possessed other characteristics of the recipient strain. 
$\mathrm{Ade}^{+}$recombinants began to appear on defined agar in $40-48 \mathrm{hr}$ when strain PU $\left(a d e^{+}-8\right)$ was used as the donor or 56-72 hr when ATCC I580 I $\left(a d e^{+}-4\right)$ was donor. It should be noted that the PU mutant grows more rapidly than the ATCC I 580 I mutant on synthetic agar (Rose \& Kloos, unpublished data). Recombinants continued to appear up until about 6 days of incubation and varied from 0.2 to $3.5 \mathrm{~mm}$. diameter depending on the time of emergence. Pigment recombinants were scored among $\mathrm{Ade}^{+}$ clones and Ade clones appearing on synthetic agar supplemented with inosine $(60 \mathrm{mg}$. 1.). The number of cells giving rise to a clone (colony forming unit) was usually two or four. Microscopic examination of wet mounts of broth and agar slant cell suspensions, that were well mixed, indicated that less than $5 \%$ of total cell clusters were composed of more than four cells.

Table 2. Genetic exchange in Micrococcus lysodeikticus

\begin{tabular}{|c|c|c|c|}
\hline Cross: donor $\times$ recipient & $\begin{array}{l}\text { Recombinant } \\
\text { phenotype }\end{array}$ & $\begin{array}{l}\text { Clones/ml. } \\
\text { suspension* }\end{array}$ & $\begin{array}{l}\text { Recombinant } \\
\text { frequency/c.f.u. }\end{array}$ \\
\hline $\begin{array}{l}\text { ATCC I } 580 \mathrm{I}\left(\text { ade }{ }^{+}-4 \text { pig-p) }\right. \\
\quad \times \text { ISU (ade pig-y) }\end{array}$ & $\begin{array}{l}\text { Ade }^{+} \\
\text {Pig-p } \\
\text { Ade }^{+} \text {Pig-p }\end{array}$ & $\begin{array}{r}10,880 \\
2,340 \\
4\end{array}$ & $\begin{array}{l}4.2 \times 10^{-5} \\
8.9 \times 10^{-6} \\
1.5 \times 10^{-8}\end{array}$ \\
\hline $\begin{array}{l}\text { ATCC I } 580 \text { I (ade pig-p) } \\
\times \text { ISU (ade pig-y) }\end{array}$ & $\mathrm{Ade}^{+}$ & 1,020 & $4.0 \times 10^{-6}$ \\
\hline ISU (ade pig-y) cells & $\begin{array}{l}\text { Ade }^{+} \\
\text {Pig-p }\end{array}$ & $\begin{array}{r}40 \\
0\end{array}$ & $\begin{array}{c}1.5 \times 10^{-7} \\
0\end{array}$ \\
\hline $\begin{array}{l}\text { PU (ade }{ }^{+}-8 \text { pig-y) } \\
\times \text { ISU (ade pig-o) }\end{array}$ & $\begin{array}{l}\text { Ade }^{+} \\
\text {Pig-y } \\
\text { Ade }^{+} \text {Pig-y }\end{array}$ & $\begin{array}{r}30,630 \\
7,040 \\
10\end{array}$ & $\begin{array}{l}1 \cdot 1 \times 10^{-4} \\
2.6 \times 10^{-5} \\
3.6 \times 10^{-8}\end{array}$ \\
\hline $\begin{array}{l}\text { PU (ade pig-y) } \\
\times \text { ISU (ade pig-o) }\end{array}$ & Ade $^{+}$ & 1,220 & $4.4 \times 10^{-6}$ \\
\hline ISU (ade pig-o) cells & $\begin{array}{l}\text { Ade }^{+} \\
\text {Pig-o }\end{array}$ & $\begin{array}{r}45 \\
0\end{array}$ & $\begin{array}{c}1.6 \times 10^{-7} \\
0\end{array}$ \\
\hline
\end{tabular}

Identification of the transfer agent in phage lysates. It was quite natural to expect that genetic exchange in the above experiment was a consequence of transduction. However, in addition to possessing high phage titres, phage lysates appeared to contain high levels of polymerized DNA. Lysates were unusually viscous. Treatment with DNase resulted in a rapid loss of viscosity and, at all levels tested, completely destroyed the ability of lysates to produce $\mathrm{Ade}^{+}$recombinants. DNase treatment did not effect the phage titre, phage adsorption, or the viability of the recipient strain.

When the temperature of the phage lysate was raised to $70^{\circ}$, the phage N6 was inactivated and unable to form plaques on an indicator strain. In addition, several other effects of phage adsorption on the recipient strain did not appear. On the other hand, the yield of $\mathrm{Ade}^{+}$recombinants remained high at all temperatures up to the melting-point of Micrococcus lysodeikticus DNA (Rosypalova, Bohacek \& Rosypal, 1966) (Table 3).

Phage specific antiserum reduced the concentration of active phages in lysates to very low levels without reducing the yield of $\mathrm{Ade}^{+}$recombinants (Table 4). Centrifugation of phage lysates, to remove large quantities of phages, produced supernatants that possessed high transfer ability. Treatment of the supernatant with antiserum decreased 
the number of active phages to 7 p.f.u./ml. without reducing the yield of recombinants. On the other hand, phages which were washed by centrifugation failed to produce recombinants. Each of the above experiments suggests that free DNA and not the phage N6 was responsible for genetic transfer of the $a d e^{+}$marker. This would imply that genetic exchange was a result of transformation.

Table 3. Effect of heat treatment of phage lysates on the yield of Ade recombinants in the cross ATCC I580I (ade+-4) $\times I S U$ (ade)

$\begin{array}{ccc}\begin{array}{c}\text { Thage N6 } \\ \text { of lysate }\end{array} & \begin{array}{c}\text { Phaque-forming } \\ \text { ability } \\ \text { (p.f.u./ml.) }\end{array} & \begin{array}{c}\text { Ade } \\ \text { transfer } \\ \text { trant } \\ \text { suspension } \dagger\end{array} \\ 32^{\circ} & 7 \cdot 3 \times 10^{10} & 8,720 \\ 70^{\circ} & 0 & 10,430 \\ 80^{\circ} & 0 & 10,015 \\ 90^{\circ} & 0 & 6,760 \\ 100^{\circ} & 0 & 35 \\ \text { ISU cells } & & 50\end{array}$

* After cooling and re-warming to $32^{\circ}$, lysates were assayed on the donor strain.

$\dagger$ Transfer suspensions contained $5 \cdot 2 \times 10^{8}$ recipient c.f.u./ml. The number of clones is the average from duplicate plates.

Table 4. Effect of the addition of specific antiserum to phage lysates and lysate supernatants on the yield of Ade recombinants in the cross ATCC I580I (ade $\left.{ }^{+}-4\right) \times I S U($ ade)

$\begin{array}{lcc}\text { Treatment } & \begin{array}{c}\text { Phage N6 plaque- } \\ \text { forming ability } \\ \text { (p.f.u./ml.)* }\end{array} & \begin{array}{c}\text { Ade } \\ \text { transfer suspension } \dagger\end{array} \\ \begin{array}{c}\text { Phage lysate: } \\ \text { No treatment }\end{array} & 3.4 \times 10^{10} & 6640 \\ \text { Normal serum } & 2.5 \times 10^{10} & 4980 \\ \text { Antiserum } & 8.7 \times 10^{5} & 5030 \\ \text { Lysate supernatant: } & 9.8 \times 10^{7} & \\ \text { No treatment } & 9.4 \times 10^{7} & 6180 \\ \text { Normal serum } & 7.0 \times 10^{\circ} & 5310 \\ \text { Antiserum } & - & 8420 \\ \text { IsU cells } & & 40\end{array}$

* After treatment, lysates were assayed on the donor strain.

$\dagger$ Transfer suspensions contained $7.8 \times 10^{8}$ recipient c.f.u. $/ \mathrm{ml}$. The number of clones is the average from duplicate plates.

Transformation by purified DNA. Reasonably high levels of DNA were isolated from both phage N6 lysates $(52-56 \mu \mathrm{g}$. $/ \mathrm{ml}$.) and lysozyme-treated cells (I·29-I·35 mg./ g. wet packed cells). The ratio RNA:DNA varied from less than $0 \cdot 0 \mathrm{I}$ to $0 \cdot \mathrm{I}$ in different preparations. DNAs contained $2-20 \%$ protein. The percent G-C of DNA isolated from phage lysates and lysozyme-treated cells was $67 \cdot 9$ and $69 \cdot 8$, respectively.

Purified DNA isolated from phage lysates and cells of Micrococcus lysodeikticus showed transforming activity for the $a d e^{+}$marker (Fig. I). The specific transforming activity of DNA isolated from lysozyme-treated cells was about $350 \mathrm{Ade}^{+}$clones $/ \mu \mathrm{g}$. DNA. The activity of DNA isolated from phage lysates was about $42 \mathrm{Ade}^{+}$clones $/ \mu \mathrm{g}$. DNA. These results confirm the implied transformation demonstrated above with crude lysates. 
Optimum conditions for transformation. Several factors which affected the yield of transformants were examined to determine conditions that would support maximum transformation frequencies. These included the age of the recipient culture, the cell density of the transfer suspension, the time of exposure to DNA, and the type of agar used in the plating medium. All experiments were conducted with the cross ATCC 1580 I $\left(a^{+} e^{+}-4\right) \times$ ISU (ade). Transfer suspensions were prepared with either phage lysates (heated I $\mathrm{hr}$ at $70^{\circ}$ to inactivate phage N6) or purified DNA $(36 \mu \mathrm{g} . / \mathrm{ml}$.). Both sources of transforming DNA indicated similar optimal conditions for all factors tested.

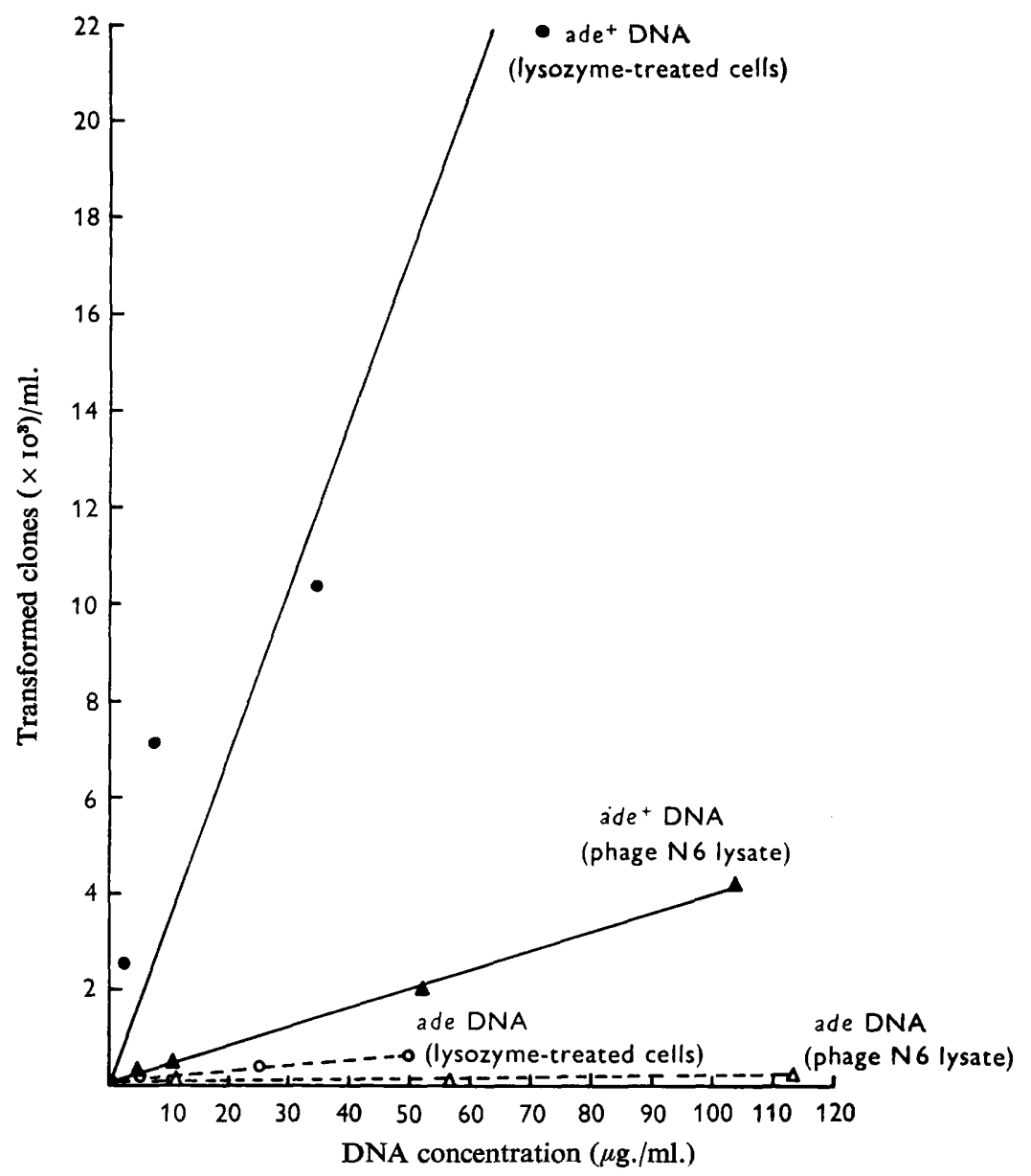

Fig. I. Effect of DNA concentration on the yield of $\mathrm{Ade}^{+}$transformants. DNA isolated from lysozyme-treated ATCC I580I $\left(a d e^{+}-4\right)$ cells. $\triangle$ DNA isolated from phage N6 lysate of $a d e^{+}-4$. ODNA isolated from lysozyme-treated ATCC I 5801 (ade) cells. $\triangle$ DNA isolated from phage N6 lysate of ATCC I580I (ade). The recipient strain was IsU (ade).

Competence of broth and agar slant recipient cultures was maximal at $14-18 \mathrm{hr}$ of incubation, corresponding to late logarithmic growth. Cultures continued to show significant competence over extended periods of incubation. For example, $72 \mathrm{hr}$ cultures produced I/IO the number of transformants produced by cultures with maximum competence. 
The concentration of the transfer suspension was optimum at about $10^{7}$ colony forming units (c.f.u.)/ml. At this concentration, the transformation frequency/c.f.u. was $2 \cdot \mathrm{I} \times \mathrm{IO}^{-3}$. At concentrations, the total number of transformants was not increased significantly. By reducing the concentration to $10{ }^{6} \mathrm{c} . f . u . / \mathrm{ml}$, , the number of transformants was reduced to $40 \%$ and the transformation frequency/c.f.u. was increased to $\mathrm{I} \cdot 3 \times 10^{-2}$.

The time course of the reaction between DNA and recipient organisms was followed over an $8 \mathrm{hr}$ period. After the appropriate exposure time, DNase $(5 \mu \mathrm{g} . / \mathrm{ml}$.) and $\mathrm{MgSO}_{4}(0.005 \mathrm{M})$ were added to the transfer suspension to prevent any further reaction by transient DNA. Transformants began to appear after I hr exposure to DNA and continued to increase in frequency up to $6 \mathrm{hr}$. Transfer suspensions that were not treated with DNase produced essentially the same number of transformants over the total exposure period. The concentration of the transfer suspension did not increase during the first $2 \mathrm{hr}$ of incubation. However, after this lag, the concentration increased 5 -fold by $6 \mathrm{hr}$.

Table 5. Survey of crosses of strains of Micrococcus lysodeikticus and

\section{Sarcina lutea}

\begin{tabular}{|c|c|c|c|c|c|c|}
\hline & & & & ient & & \\
\hline & & Ade & nes $/ \mathrm{m}$ & nsfer st & sion* & \\
\hline Donor & $\begin{array}{r}\text { ATCC } \\
4698 \\
(\text { ade })\end{array}$ & $\begin{array}{l}\text { ATCC } \\
\text { I } 580 \mathrm{I} \\
\text { (ade) }\end{array}$ & $\begin{array}{c}\mathrm{PU} \\
\text { (ade) }\end{array}$ & $\begin{array}{c}\mathrm{UM} \\
\text { (ade) }\end{array}$ & $\begin{array}{l}\text { WRU } \\
\text { (ade) }\end{array}$ & $\begin{array}{c}\text { ISU } \\
\text { (ade) }\end{array}$ \\
\hline None & 0 & 5 & 5 & 15 & 25 & IO \\
\hline ATCC 4698 (ade) & 0 & - & - & - & - & 940 \\
\hline ATCC I580I $\left(\right.$ ade $\left.^{+}-4\right)$ & 0 & $\begin{array}{c}620 \\
(770)\end{array}$ & 0 & - & - & $\begin{array}{c}4,010 \\
(2,260)\end{array}$ \\
\hline ATCC I 5801 (ade) & - & $\begin{array}{c}5 \\
(5)\end{array}$ & - & 一 & - & $\begin{array}{r}420 \\
(370)\end{array}$ \\
\hline $\operatorname{CCM} I 335\left(\right.$ ade $\left.^{+}\right)$ & - & - & - & - & - & 7,940 \\
\hline PU $\left(a d e^{+}-8\right)$ & 0 & 100 & 15 & 25 & I 50 & 17,590 \\
\hline PU (ade) & - & - & 5 & - & - & 780 \\
\hline UM $\left(a d e^{+}-I\right)$ & - & - & - & 55 & - & 3,420 \\
\hline UM (ade) & - & - & - & 10 & - & 470 \\
\hline WRU $\left(\right.$ ade $\left.e^{+-I}\right)$ & - & - & - & - & $(85)$ & - \\
\hline WRU (ade) & - & - & - & - & (25) & - \\
\hline ISU $\left(\right.$ ade $\left.e^{+}-I\right)$ & - & - & - & - & - & $(2,480)$ \\
\hline ISU (ade) & - & (40) & - & - & - & (I5) \\
\hline Sarcina lutea & & & & & & \\
\hline $\operatorname{ATCC} 272\left(\right.$ ade $\left.^{+}\right)$ & 0 & 105 & 25 & 20 & 210 & 16,470 \\
\hline
\end{tabular}

* Transfer suspensions were prepared with heat-inactivated phage N6 lysates (without brackets) or with lysozyme lysates (brackets). Suspensions contained $\mathrm{I} \cdot 2-\mathrm{I} \cdot 7 \times 10^{7}$ recipient c.f.u. $/ \mathrm{ml}$. Crosses that were not performed are indicated by symbol - . The number of clones is the average from duplicate plates.

Different Difco agars used in the preparation of the defined medium had a pronounced effect on the recovery of transformants. The three agars tested and their degrees of purity are as follows: Purified Agar $>$ Special Agar-Noble > Bacto-Agar. The number of transformants was found to vary inversely with the degree of purity of the agar. For example, the transformation frequency/c.f.u. on Purified Agar was $4.5 \times 10^{-6}$, on Special Agar-Noble, $2.5 \times 10^{-3}$, and on Bacto-Agar, 6.7 $\times 10^{-2}$. 
Survey of donor and recipient competence of strains. The ability of different strains of Micrococcus lysodeikticus to act as donors and recipients of an adenine marker was tested by a number of intra- and inter-strain crosses (Table 5). In addition, the related Sarcina lutea was tested as a donor. Crosses were initially made with phage-inactivated lysates, except when strains IsU and WRU were donors. Both of these strains were unable to propagate phage N6 to high titres and strain ISU was not lysed by this phage. In crosses with these donors, lysozyme lysates were substituted to prepare transfer suspensions. Control crosses using DNase-treated lysates failed to produce $\mathrm{Ade}^{+}$ recombinants. All strains were competent donors of the adenine marker. The relative donor competence of strains must be taken with some caution as the amount of DNA in lysates was not determined. Significant recipient competence was demonstrated in strains ISU, ATCC I580I, and WRU; the competence of strains PU and UM was questionable in this experiment, with Special Agar-Noble in the plating medium. It was interesting to find that on Bacto-Agar all strains, except ATCC 4698, showed good recipient competence. A comparison of recipient competence on the two different agars is shown in Table 6. As was expected, the relative competence of strains was similar in crosses prepared with either lysates or purified DNA.

Table 6. Recipient competence of Micrococcus lysodeikticus strains on different plating agars

\begin{tabular}{lrc}
$\begin{array}{c}\text { Recipient strain } \\
\text { (ade) }\end{array}$ & \multicolumn{2}{c}{$\begin{array}{c}\text { Ade } \\
\text { clones/ml. transfer } \\
\text { suspension* }\end{array}$} \\
\cline { 2 - 3 } ATCC 4698 & 0 & $\begin{array}{c}\text { Special Agar- } \\
\text { Noble }\end{array}$ \\
ATCC 1580I & 14, I 20 & 0 \\
PU & 1,740 & 440 \\
UM & 7,380 & 10 \\
WRU & 9,880 & 30 \\
ISU & 216,780 & 80 \\
& & 8,170
\end{tabular}

* Transfer suspensions were prepared with purified DNA ( $36 \mu \mathrm{g}$. in $0.5 \mathrm{ml}$. SSC $+0.5 \mathrm{ml}$. P broth) isolated from lysozyme-treated ATCC $1580 \mathrm{I}\left(\right.$ ade $\left.{ }^{+}-4\right)$ cells. Suspensions contained $3 \cdot 0-3 \cdot 4 \times \mathrm{IO}^{6} \mathrm{recip}-$ ient c.f.u./ml. The number of clones is the average from duplicate plates.

\section{DISCUSSION}

Transformation in Micrococcus lysodeikticus was not initially observed by the usual method of testing purified DNA, but was found unexpectedly with micrococcal phage lysates which were being screened for transducing activity. The role of free DNA in genetic transfer was implied by the absence of recombinants in crosses with phage N6 lysates treated with DNase. The phage N6 did not appear to be necessary for genetic transfer as inactivation by heat or specific antiserum failed to decrease the yield of recombinants. Conclusive evidence of transformation was obtained by the isolation of transforming DNA. The specific transforming activity of DNA isolated from lysozyme-treated cells was higher than with DNA isolated from phage lysates. However, it would be expected that the rather vigorous treatment used in the preparation of phage lysates could result in shearing of the highly polymerized DNA. Also it is uncertain to what extent propagation of phage may have influenced DNA activity. 
Transformation mediated by a phage lysate is unusual, particularly with the high frequencies observed in this study. One explanation may be that Micrococcus lysodeikticus releases transforming DNA into the surrounding medium during phageinduced lysis without significant degradation. If the organism possesses active DNase(s), it probably is not active on the homologous DNA. Studies by Campbell, Evans, Perry \& Niven (I96I) have indicated that the extracellular DNase, produced by the related Micrococcus sodonensis, was inactive against the homologous DNA. Further studies would be required to correlate the observations in the two species.

Recombination between various adenine-dependent donor strains and the ISU adenine-dependent recipient suggests that the auxotrophs may carry mutations at different sites. That these mutations may be point mutations is implied from the ease with which adenine-independent mutants can be obtained from auxotrophic strains. By comparison, strain ATCC 4698 appears to have a deletion or several mutant sites, as adenine-independent mutants were not recovered in numerous attempts, and it could not be transformed with an adenine marker. It would be of interest to know the adenine phenotype of Fleming's original isolate before it was subjected to selective processes in different laboratories.

Genetic exchange between Sarcina lutea and Micrococcus lysodeikticus provides additional evidence of the close relationship of these organisms. Kocur \& Martinec (I962) have suggested that both be classified as Micrococcus luteus. The transformation system described in this paper may be useful in testing the genetic compatability of different micrococci to further clarify taxonomic relationships.

We are pleased to acknowledge Dr G. V. Gooding, Jun. and Mr J. B. Young for their suggestions and assistance in the preparation of phage N6 antiserum. We also wish to thank Dr J. B. Evans and Dr F. Armstrong for their helpful discussions and encouragement during these studies.

This investigation was partially supported by the Public Health Service Grant AI 08255-0I from the National Institute of Allergy and Infectious Diseases.

This is paper number 2624 of the Journal Series of the North Carolina State University Agricultural Experiment Station, Raleigh, North Carolina. One of the authors (L. M. S.) is a NDEA Predoctoral Fellow.

\section{REFERENCES}

Brown, A. H. (1946). Determination of pentose in the presence of large quantities of glucose. Archs. Biochem. II, 269.

BURGI, E. (1955). A study of abortive infection in a mutant strain of Micrococcus lysodeikticus infected with a bacteriophage. Ph.D. thesis, Cornell University, New York.

Campbell, J. N., Evans, J. B., Perry, J. J. \& Niven, C. F., Jun. (I96I). An extracellular material elaborated by Micrococcus sodonensis. J. Bact. 82, 828.

Demerec, M. E., Adelberg, E. A., Clark, A. J. \& Hartman, P. E. (I966). A proposal for a uniform nomenclature in bacterial genetics. Genetics 54, $6 \mathrm{I}$.

Dische, Z. (1955). Color reactions of nucleic acid components. In The Nucleic Acids. Ed. by E. Chargaff and J. N. Davidson, vol. 1, p. 285. New York and London: Academic Press.

FEINER, R. R. (1967). Ultraviolet radiation-sensitive mutants of Micrococcus lysodeikticus. J. Bact. 94, 1270.

Feiner, R. R., Meyer, K. \& Steinberg, A. (I946). Bacterial lysis by lysozyme. J. Bact. 52, 375 .

Fleming, A. (1922). On a remarkable bacteriolytic element found in tissues and secretions. Proc. R. Soc. B 93, 306. 
Fleming, A. \& Allison, V. D. (I927). On the development of strains of bacteria resistant to lysozyme action and the relation of lysozyme action to intracellular digestion. Br. J. exp. Path. 8, 214.

GrulA, E. A. (1962). A comparative study of six cultures of Micrococcus lysodeikticus. Can. J. Microbiol. 8, 855 .

KLoos, W. E. (1968). Evidence of genetic exchange in Micrococcus lysodeikticus. Bact. Proc., p. 55.

Kocur, M. \& Martinec, R. (1962). A taxonomic study of the genus Micrococcus. Folia Fac. Sci. Natur. Univ. Purkynianae Brunensis 3, $\mathrm{I}$.

Lowry, O. H., Rosebrough, N. J., Farr, A. L. \& Randall, R. J. (I95I). Protein measurement with the Folin phenol reagent. J. biol. Chem. 193, 265.

MARMUR, J. (I96I). A procedure for the isolation of deoxyribonucleic acid from micro-organisms. J. molec. Biol. 3, 208.

MARMUR, J. \& DotY, P. (1962). Determination of the base composition of deoxyribonucleic acid from its thermal denaturation temperature. J. molec. Biol. 5, 109.

Mejbaum, W. (1939). Über die Bestimmung kleiner Pentosemengen, insbesondere in Derivaten der Adenylsäure. Z. physiol. Chem. 258, I 17.

NAYLOR, H. B. \& BURGI, E. (1956). Observations on abortive infection of Micrococcus lysodeikticus with bacteriophage. Virology 2, 577.

Oxubo, S., Nakayama, H., Sekiguchi, M. \& Takagi, Y. (1967). A mutant of Micrococcus lysodeikticus defective in a deoxyribonuclease activity specific for ultraviolet-irradiated DNA. Biochem. biophys. Res. Commun. 27, 224.

Rosypalova, A., Bohacex, J. \& Rosypal, S. (1966). Deoxyribonucleic acid base composition of some micrococci and sarcinae. Antonie van Leeuwenhoek 32, 192.

SAITo, H. \& MiURA, K. (1963). Preparation of transforming deoxyribonucleic acid by phenol treatment. Biochem. biophys. Acta 72, 619.

STECHSCHULTE, A. L. (I96I). Isolation of biochemical and chromogenic mutants of Micrococcus lysodeikticus using lysozyme as the selective agent. Biol. Ser. Cath. Univ. Am. No. 68.

SWANSTROM, M. \& ADAMs, M. H. (195I). Agar layer method of production of high titre phage stocks. Proc. Soc. expt. Biol. Med. 78, 372.

WolIN, H. L. \& NAYLOR, H. B. (1957). Basic nutritional requirements of Micrococcus lysodeikticus. J. Bact. 74, 163 .

\section{Note added in proof}

It has been brought to our attention that Chakrabarti \& Litwack (Bact.Proc., p. 75, 1960) may have had an indication of a transformation process in $M$. lysodeikticus by their apparent transfer of lysozyme resistance tolysozyme sensitive cultures. Recently workers in two other laboratories (Mahler \& Grossman; Okubo \& Nakayama) have independently conducted preliminary studies of transformation of ultra-violet radiation resistance markers in $M$. lysodeikticus. 